\title{
Dalış Turizmi Emniyeti: Risk Faktörleri ve Çözüm Önerileri*
}

\author{
Safety At Scuba Diving Tourism: Risk Factors and Solution Offers
}

\author{
Hümeyra DOĞRU**, Burcu ÇELIK***, Burcu Selin YILMAZ**** \\ **Araş. Gör., Dokuz Eylül Üniversitesi İşletme Fakültesi Turizm İşletmeciliği Bölümü Tınaztepe Kampüsü, 35390 Buca, İzmir. \\ E-posta: humeyra.dogru@deu.edu.tr \\ ORCID: 0000-0002-3595-1274 \\ ***Araş. Gör., Dokuz Eylül Üniversitesi Denizcilik Fakültesi Deniz Ulaştırma İşletme Mühendisliği Bölümü Tınaztepe Yerleşkesi, 35390 Buca, İzmir. \\ E-posta: burcu.celik@deu.edu.tr \\ ORCID: 0000-0003-0319-7454 \\ ****Prof. Dr., Dokuz Eylül Üniversitesi İşletme Fakültesi Turizm İşletmeciliği Bölümü Tınaztepe Kampüsü, 35390 Buca, İzmir. \\ E-posta: selin.yilmaz@deu.edu.tr \\ ORCID: 0000-0002-6997-6146
}

MAKALE BILGILERI

Makale işlem bilgileri:

Gönderilme tarihi: 15 Kasım 2018

Düzeltme: 11 Ocak 2019

Kabul: 1 Şubat 2019

Anahtar sözcükler: Macera turizmi, Emniyet, Dalış merkezleri, Sualtı dalış turizmi.

\section{ARTICLE INFO}

Article history:

Submitted: 15 November 2018

Resubmitted: 11 January 2019

Accepted: 1 February 2018

Key words: Adventure tourism, Safety, Diving centers, Scuba diving tourism.

\begin{abstract}
$\ddot{O Z Z}$
Macera turizmi etkinliklerinden biri olan sualtı dalış turizmi destinasyonlar açısından potansiyel gelir yaratabilecek alternatif bir turizm türü olarak öne çıkmaktadır. Sualtı dalış turizminde emniyet sorunu ise turistlerin sağlığı ve emniyeti açısından üzerinde durulması gereken konulardan biri olmasına rağmen alanyazında genellikle göz ardı edilen bir husus olmuştur. Bu çalışmada, sualtı dalış turizmine katılan bireylerin karşılaștıkları kaza ve yaralanma deneyimleri, bunları olușturan risk faktörleri ve bu kazaları önlemeye yönelik gerçekleștirilen emniyet uygulamaları ortaya konulmaktadır. Bu kapsamda Türkiye'deki önemli su altı dalıș noktalarına sahip İzmir ilinde faaliyet gösteren dalış merkezlerinde çalışan dalış eğitmenleri ile derinlemesine görüşmeler gerçekleştirilmiştir. Veriler içerik analizi yöntemiyle analiz edilmiş ve bulgular görüşülen katılımcılardan alıntılarla zenginleștirilmiștir. Araștırma sonuçlarına göre dalıs turizmi aktivitelerinde karșılașılan kaza ve yaralanmaları oluşturan risk faktörleri dört ana başlık altında incelenmiştir. Bunlar dalıcılarla ilgili, donanımla ilgili, çevresel ve organizasyon/yönetimsel risk faktörleridir. Ayrıca katıımcıların dalış turizmi emniyetini sağlamaya yönelik önerileri ortaya konulmuştur.
\end{abstract}

\section{ABSTRACT}

Scuba diving tourism stands out as one of the alternative tourism activities for destinations due to its potential to generate revenue. Safety at scuba diving tourism is an outstanding issue in relation to tourists' health and their safety; however, it is mostly neglected in tourism literature. This study aims to reveal the most common visitor accidents and injuries experienced during scuba diving tourism activities, the risk factors for client injuries and the safety and risk management practices applied by diving operators. In-depth interviews were conducted with diving instructors of diving centers located in Izmir which has some of the most important scuba diving sites in Turkey. Content analysis was performed on data and the findings were enriched with the quotes from participants. According to study findings, risk factors resulting in accidents and injuries experienced in scuba diving tourism activities were summarized into four categories: client-related, equipment-related, environment-related and organization/management-related. Then, solution offers to ensure scuba diving tourism safety were revealed.

\section{Giriş}

Değişen tüketici tercih ve beklentilerinin bir sonucu olarak bireyler geleneksel deniz, kum, güneş turizminin yanı sıra alternatif turizm türle-

\footnotetext{
* Bu çalışma, 23-24 Şubat 2018 tarihlerinde İzmir'de düzenlenen 4. Ulusal Deniz Turizmi Sempozyumu'nda sunulmuş sözlü bildirinin geliştirilmiş versiyonudur.
}

rine de yönelmektedir. Günümüz turistlerinin daha fazla değer talep ettikleri bir ortamda alternatif ürünlerle çekirdek turizm ürünlerini zenginleştirmek rekabet gücü elde etmeyi hedefleyen turizm çekim merkezleri için kaçınılmazdır (Duman, Kozak ve Uysal 2007). Diğer taraftan alternatif turizm türlerinin geliştirilmesi, turizmin mevsimsellik özelliğinin azaltılması ve mevcut 
kaynakların sürdürülebilir bir şekilde kullanılması açısından önemlidir.

1930'larda ticarileşmeye başlayan fakat 1967 yılında itibaren ciddi bir hızla gelişen ve bugün milyar dolarlık bir endüstri haline gelen sualtı dalış sporu dünyanın en hızlı gelişen rekreasyonel faaliyetlerinden biridir. Bu süreçte kısıtlı sayıdaki maceracılar tarafından yapılan sualtı dalış sporu, tropikal ve 1lıman destinasyonlarda yapılan bir tatil aktivitesi ve boş zaman faaliyeti haline gelmiştir (Musa ve Dimmock 2012). Bu gelişmenin ve ticarileşmenin bir sonucu olarak bu spora yönelik becerilerin geliştirilmesi ve eğitimler için uluslararası geçerliliği olan sertifikasyon sistemleri oluşturulmuştur. PADI (Proffessional Association of Diving Instructors) (2017) istatistiklerine göre dünyada toplam 25 milyondan fazla dalıcı bulunmaktadır. Kış turizminden sonra en hızlı büyüyen ikinci spor turizmi çeşitlerinden olan sualtı dalış endüstrisine, her yıl bir milyondan fazla sertifikalı yeni dalıcı eklenmektedir (Dünya Turizm Örgütü 2016). Türkiye'nin öne çıkan hedef pazarlarından biri olan Avrupa ise dalış turizmi açısından önemli bir kaynak pazar konumundadır. Özellikle Almanya, Fransa ve İngiltere gibi Batı Avrupa ülkeleri eşsiz dalış bölgeleri ve deneyimleri arayan dalıcılara sahip güçlü pazarlar olarak öne çıkmaktadır (Cbi.eu 2018).

Uluslararası alanyazında dalış turizmiyle ilgili yapılan çalışmalar çoğunlukla dalış turizminin sürdürülebilirlik açısından önemine, ekonomik katkılarına, dalıcıların motivasyon ve tatmini ile paydaşların bu turizm türünün gelişmesine yönelik etkilerine odaklanmıştır (Lamb vd. 2014; Dimmock ve Musa 2015; Fuchs, Reichel ve Shani 2016). Türkçe yazındaki sınırlı sayıdaki akademik çalışmalar ise dalış turizmini daha bütüncül bir açıdan ele aldığı görülmektedir. Yaşar (2011) araştırmasında dalış eğitmenleriyle yaptığı görüşmeler sonucunda Saros Körfez'inde sualtı dalış turizminin gelişimini etkileyen faktörleri, dalış mevkilerini ve bu turizm çeşidinin uluslararası bir boyut kazanması için yapılması gereken çalışmaları ortaya koymaktadır. Yarmacı, Keleş ve Ergil (2017) ise çalışmalarında Antalya ilinin Kaş bölgesinde faaliyet gösteren dalış turizmi paydaşlarıyla görüşmeler gerçekleştirerek sualtı dalış turizminin sürdürülebilirlik açısından önemini vurgulamışlardır.

Dalış turizminde risk ve emniyet yönetimiyle ilgili çalışma sayısı hem uluslararası hem de ulusal yazında oldukça sınırlıdır. Bu çalışmada ise alanyazındaki araştırmalardan farklı olarak sadece dalış turizminde emniyet konusuna odaklanılmıştır. Bu kapsamda çalışmanın amacı macera turizmi çeşitlerinden biri olan sualtı dalış turizmi aktivitelerinde karşılaşılan kaza ve yaralanmalar ile bunları oluşturan risk faktörlerini saptamak ve bu faktörlere yönelik gerçekleştirilen emniyet uygulamalarını ortaya koymaktır. Ayrıca dalış eğitmenlerinin dalış kaza ve yaralanmalarının nasıl önlenebileceğiyle ilgili önerileri çerçevesinde ülkemizde dalış turizmi emniyetinin nasıl sağlanabileceği tartışılmıştır.

\section{DALIŞ TURIZMI EMNIYETI}

Alternatif turizm türlerinden biri olan sualtı dalış turizmi alanyazında dalıcının sualtında nefes almak için kullandığ 1 bağımsız bir nefes alma aparatı ile gerçekleştirdiği sualtı dalış aktivitesi olarak tanımlanmaktadır (Fuchs, Reichel ve Shani 2016). Çoğunlukla macera turizmi kapsamında ele alınan rekreasyonel sualtı dalış aktivitesi dünya çapındaki uluslararası ve yerel seyahat endüstrisinin önemli bir parçasını oluşturan ve gelişen bir niş pazardır (Maccarthy, O'neill ve Williams 2006). Macera turizmi aktivitelerinin birçoğu gibi dalış turizmi de heyecan ve yüksek seviyede risk içermektedir. Bu nedenle ziyaretçilerin sağlık ve emniyetini tehdit eden ciddi kazalar ve yaralanmalar meydana gelebilmektedir.

Bentley, Cater ve Page (2010) macera ve ekoturizm operatörleri üzerine yaptıkları ve karma yöntem kullandıkları çalışmalarında emniyeti tehdit eden risk faktörlerinin zorlu ve değişken hava koşulları ile müşteri yetenekleri ve davranışları olduğunu ortaya koymuşlardır. Macera ve ekoturizm operatörleri için kaza kontrol boyutları modelini ortaya koyan araştırmacılar diğer çalışmalarla (Page, Bentley ve Walker 2005; Bentley, Page ve Macky 2007) benzer bir şekilde ciddi kazalarla karşılaşılma sıklığının basit kazalara göre çok daha az olduğu sonucuna ulaşmışlardır. En fazla karşılan kazaların kayma, sendeleme ve 
düşme gibi ufak çaplı kazalar olduğunu belirten yazarlar operatörlerin değişken hava koşullarına göre rota planlamasını iyi yapmaları gerektiğini vurgulamışlardır.

1980-1987 yılları arasında Avustralya ve Yeni Zelanda'da yayınlanan raporları inceleyen Edmonds ve Walker (1989) insan faktörü sonucu oluşan dalış kazalarıyla ilgili istatistikleri analiz etmişlerdir. Heyecan ve stres sonucu oluşan panik, donanımın yanlış kullanımı, fiziksel olarak dalışa uygun olmamak, ilaç kullanımı, mevcut tıbbi hastalıklar ciddi kazalara sebebiyet vermektedir. Emniyetli bir dalış deneyimi yaşayabilmek için dalış için uygun fiziksel ve psikolojik şartlara sahip olmak, kazaları önlemek ve yönetmek konusunda eğitim almış olmak, donanımın sınırları hakkında bilgi sahibi olmak ve çevrenin de potansiyel tehlikeler barındırdığının farkında olmak oldukça önemlidir.

Page, Bentley ve Walker (2005) Yeni Zelanda ve İskoçya'daki macera turizmi operatörleri üzerine yaptıkları karşılaştırmalı nicel araştırmalarında çok az işletmenin risk değerlendirme prosedürlerini uyguladıkları sonucuna ulaşmışlardır. Buna karşın personelin eğitilmesi ve seçilmesi ile donanımların düzenli kontrol edilmesi kazaları önleyici tedbirler olarak ele alınmaktadır. Ayrıca müşterilerin muhtemel kaza ve yaralanma durumlarında nasıl davranmaları gerektiğiyle ilgili önceden uyarılmaları gerekmektedir. Dolayısıyla macera turizmi operatörlerinin hem sorumlu hem de şeffaf olmaları emniyet açısından oldukça önemlidir. Buckley de (2010) benzer bir şekilde ticari su sporu turlarına katılanları gözlemlediği çalışmasında hem rehberlerin kendi aralarındaki hem de müşterilerle olan iletişiminin ticari macera turizmi aktivitelerinde müşterileri ciddi tehlikelerden korumak ve müşteri tatmini sağlamak açısından hayati olduğunu vurgulamıştır. Eksik iletişim katılımcıları riskli durumlara sokabilmekte ve müşteri tatminsizliğine yol açmaktadır.

Dimmock ve Wilson (2009) macera ve dalış turizmi aktivitelerindeki emniyet ve konforu etkileyen kısıtlar üzerine Avustralya'da yaptıkları araştırmada dalıcılarla yüz yüze görüşmeler gerçekleştirmişlerdir. Dalış turizmini etkileyen k1sitları fiziksel, sosyal, psikolojik ve görsel olmak üzere dört kategoride ele alan araştırmacılar su sıcaklığının ani düşüşü, aşırı güç harcama ve sık nefes alma sonucu oluşan derinlik sarhoşluğu, dalış eşini tanımama, korku, heyecan ve stres ile sudaki görüş kısıtı gibi faktörlerin dalış konforunu etkilediğini belirtmişlerdir. Bunların yanı sıra Miller ve Taubman-Ben-Ari'ye (2004) göre sualtının tahmin ve kontrol edilememe özelliği ile dalıcıların donanıma ve kendi dalış becerilerine aşırı güvenmeleri sonucu riskli durumlar ortaya çıkabilmektedir.

Macera turizmi operatörlerinin organizasyonel ve yönetimsel yapısı, operasyon kararları, donanımın bakımı, çevresel risk değerlendirmesi, kalite yönetim sistemlerinin düzeyi, rehber-müşteri oranı ve müşteri deneyiminin aktif yönetimi gibi unsurlar oldukça önemlidir (Page, Bentley ve Walker 2005). Benzer bir şekilde yönetimsel unsurlara dikkat çeken Coxon, Dimmock ve Wilks'in (2008) dalış turizmi operatörlerinin kullanımına yönelik oluşturdukları risk değerlendirme süreci döngüsüne göre dalış operatörü öncelikle tehlikeleri belirlemelidir. Bu süreçte belirlenen tehlikeleri kontrol etmeye yarayacak standartlar varsa standartları takip etmeli ve mevcut talimatlardaki uygulamaları hayata geçirmelidir. Eğer standartlar veya talimatlar yoksa etkili bir risk yönetimiyle riskin boyutunu belirlemeli ve riski azaltacak ya da yok edecek uygun kontrol önlemini almalıdır. En son aşamada ise tüm bu süreci gözden geçirerek kontrol önlemlerinin riskleri yeteri kadar azaltıp azaltmadığını ve tehlikelerin hala mevcut olup olmadığını kontrol etmelidir.

\section{YÖNTEM}

$\mathrm{Bu}$ araştırmada, nitel araştırma yöntemlerinden yarı-yapılandırılmış derinlemesine görüşme yöntemi kullanılmıştır. Araştırmada veriler dalış ve macera turizmi emniyeti ile ilgili yazın taramasından sonra oluşturulan soruların yer aldığ 1 görüşme formu ile elde edilmiştir. Katılımcılara yöneltilen sorular Ek 1'de verilmiştir. Veriler 11 Aralık 2017 - 21 Ekim 2018 tarihleri arasında toplanmış, yapılan görüşmeler katılımcıların onayı alınarak kayıt altına alınmıştır. Her bir katılımcı için görüşme süresi 26-140 dakika arasında de- 
ğişmiştir. Görüşmelerden elde edilen ses kayıtları bilgisayar ortamına aktarılarak yazılı hale getirilmiştir. Yazılı hale getirilen veriler her üç yazar tarafından da okunmuş ve yazarların bir araya gelmesiyle içerik analizi yöntemi ile analiz edilmiştir.

Bilgisayar dosyasına aktarılan veri öncelikle araştırma sorularına göre parçalara ayrılmış, veri parçalarına kodlar verilmiş ve bu kodlar bir araya getirilerek kategoriler oluşturulmuştur. Patton'a (2002) göre içerik analizi nitel veri setindeki temel bileşenleri ve anlamları belirlemek için verinin indirgenmesi sürecidir. İçerik analizinde veri, bulguları sistematik ve açık bir şekilde sunabilmek amacıyla araştırma soruları tarafından belirlenen bazı temalara göre özetlenir ve yorumlanır (Creswell 2013). Araştırmada bulgular katılımcıların söylediklerinden doğrudan alıntılar yapılarak okuyucuya sunulmuştur. Nitel veri analizinde betimsel alıntılara yer vermek verilerin ve ulaşılan sonuçların anlatım olarak birbirine çok yakın olmasını sağlar, anlatımı zenginleştirir ve güçlendirir (Wolcott 1994).

Araştırmada göreli olarak daha küçük bir örneklem grubu oluşturmak ve bu örneklemde çalışılan soruna taraf olabilecek bireylerin çeşitliliğini en üst düzeyde yansıtmak amacıyla amaçlı örnekleme yöntemlerinden maksimum çeşitlilik örneklemesi kullanılmıştır (Yıldırım ve Şimşek 2013). Araştırmanın örneklemini İzmir ilinin turist profili ve turistik ürün çeşitliliği bakımından farklılık gösteren ilçelerinde konumlanmış dalış merkezlerinde çalışan dalış eğitmenleri oluşturmaktadır. Türkiye Sualtı Sporları Federasyonu'nun (TSSF) internet sitesine göre İzmir'de faaliyet gösteren kayıtlı toplam 16 dalış merkezi bulunmaktadır (TSSF 2018). İletişime geçilen dalış merkezi eğitmenlerinden bazılarının görüşme için uygun olmadıklarını belirtmeleri nedeniyle çalışma kapsamında 10 farklı merkezden birer kişi olmak üzere toplam 10 dalış eğitmeni ile yüz yüze görüşmeler gerçekleştirilmiştir. Araştırmaya katılan eğitmenlere ait görüşme bilgileri Tablo 1'de verilmektedir. Görüşülen dalış merkezi eğitmenlerinin çoğunluğu 20 yılın üzerinde dalış eğitmenliği tecrübesine sahip hem yurtiçinde hem de yurtdışında farklı dalış merkezlerinde çalışmış ve çoğunluğu İngilizce olmak üzere en az bir yabancı dil konuşabilen eğitmen dalıcilardır.

Araştırma konusunun seçiminde çalışmanın ilk yazarının bir yıldız dalıcı, ikinci yazarının ise iki yıldız dalıcı olması etkili olmuştur. Aynı zamanda araştırmacıların dalış deneyimine sahip kişiler olması yapılan görüşmelerde etkileşimi güçlendirmiş ve katılımcıların görüşlerini daha açıkça dile getirmelerini sağlamıştır.

\section{BULGULAR}

Çalışma kapsamında görüşülen dalış merkezi eğitmenlerinin görüşme sorularına verdikleri cevaplar doğrultusunda çalışmanın bulguları aşağıdaki başlıklar altında derlenmiştir.

\section{Dalış Turizmine Katılan Turist Profili}

Araştırma kapsamında dalış eğitmenlerine dalış turizmine katılan bireylerin yerli/yabancı olup olmadığı, hangi kanallardan kendilerine ulaştıkları ve doğrudan dalış amaçlı gelip gelmedikleri sorulmuştur. Katılımcıların bazıları çoğunlukla yerli dalıcılara hitap ettiklerini belirtirken, bazıları da fiyatları çok düşürdüğü için yerlilerle çalı̧̧mayı tercih etmediklerini belirtmişlerdir. Dalış merkezlerinin hedef kitlesi bulundukları konuma, uyguladıkları fiyatlara, süreklilik gösteren müşteri profiline, işbirliği halinde çalıştıkları kurumlara göre değişmektedir.

Tablo 1. Görüşme Yapılan Katılımcılara Ait Bilgiler

\begin{tabular}{lcclr}
\hline Katılımcı & Cinsiyet & $\begin{array}{l}\text { Eğitmenlik } \\
\text { Süresi (yıl) }\end{array}$ & $\begin{array}{l}\text { Bağlı Olduğu } \\
\text { DalışMerkezinin } \\
\text { Faaliyet Yeri }\end{array}$ & $\begin{array}{c}\text { Görüşmes } \\
\text { Süresi (dk.) }\end{array}$ \\
\hline K1 & Kadın & 5 & Karaburun & 140 \\
\hline K2 & Erkek & 26 & Seferihisar & 50 \\
\hline K3 & Erkek & 20 & Seferihisar & 62 \\
\hline K4 & Erkek & 32 & Gümüldür & 52 \\
\hline K5 & Erkek & 25 & Foça & 66 \\
\hline K6 & Erkek & 21 & Karşıyaka & 66 \\
\hline K7 & Kadın & 2 & Seferihisar & 26 \\
\hline K8 & Erkek & 18 & Karaburun & 29 \\
\hline K9 & Erkek & 7 & Karaburun & 50 \\
\hline K10 & Erkek & 10 & Seferihisar & 30 \\
\hline
\end{tabular}


Katılımcıların hemen hemen hepsi dalış yapmaya gelenlerin arkadaş veya tanıdık tavsiyesi ile, yani ağızdan ağıza iletişim yoluyla dalış merkezine ulaştıklarını belirtmişlerdir. Görüşülen dalış merkezlerinin hepsinin bir internet sitesi olmasına rağmen, internet sitesinde çoğunlukla sadece iletişim bilgilerinin verildiği, sadece iki dalış merkezinin interneti aktif bir satış kanalı olarak kullandığı tespit edilmiştir. Bazı dalış merkezleri ise Facebook, Instagram gibi sosyal medya kanallarını dalış yapmak isteyen turistlere ulaşmada etkin olarak kullandıklarını vurgulamışlardır. Bunun yanı sıra Seferihisar ve Gümüldür gibi tatil beldelerinde bulunan dalış merkezleri otellerle anlaşmalar yapmaktadır. Bu şekilde çalışan dalış merkezleri otellere gelen turistlere öncelikle bilgilendirme yaparak, ücretsiz deneme dalışı sonrası kişisel satış yoluyla dalış eğitimi satışı yaptıklarını da belirtmişlerdir. Özel şirketlerin, üniversitelerin veya çeşitli kurumların sualtı toplulukları ise dalış merkezlerinin düzenli olarak hizmet verdiği dalıcı kitlesini oluşturmaktadır. Ayrıca PADI sertifikasyon merkezinin dergileri ve internet sitesi vasıtasıyla dalış merkezine ulaşan veya yoldan geçerken dalış teknesini görüp bilgi almak isteyen bağımsız dalıcılar da bulunmaktadir.

Yerli dalıcılara hizmet veren merkez temsilcileri Türkiye'de yaşanan herhangi olumsuz bir gelişme sonrası (deprem, kaza, şehit haberleri vb.) dalıcıların bir süre dalışa gelmediklerini, bireylerin psikolojik olarak rahat hissetmelerinin dalış için oldukça önemli bir ön koşul olduğunu belirtmişlerdir. Ayrıca katılımcıların büyük çoğunluğu kazalarla karşılaşma sıklığında yerli ve yabancı dalıcılar arasında herhangi bir farklılık bulunmadığını, fakat yabancıların dalış sporuna daha disiplinli yaklaştıklarını beyan etmişlerdir.

\section{En Sık Karşılaşılan Kaza ve Yaralanmalar}

Katılımcılar dalış turizmi kapsamında en sık karşılaşılan kaza, hastalık ve yaralanmaların tüpün yatay konumlandırılmaması sonucu ayağa düşmesi, tekne veya şişme bottan kayarak düşme, kulak eşitlememe nedeniyle kulak zarı zedelenmesi, orta kulak barotravması, kesik veya küçük çizikler, su altında oluşabilecek kramp ve spazmlar ile sinüs patlaması olduğunu belirtmiş̧lerdir.
Bunlara ek olarak basınç gösterge konsolunun patlaması sonucu yaralanma, deniz canlıları tarafından isırılma, nitrojen narkozu (derinlik sarhoşluğu), hipotermi, arteryal gaz embolisi, kalp krizi gibi durumlar nadiren de olsa görülebilmektedir. Sanılanın aksine bağımsız aletli dalışta dekompresyon (vurgun) hastalığıyla çok sık karşılaşılmamaktadır. Katılımcıların hepsi dekompresyonun, dalış limitlerine uyulmaması, emniyet beklemesi yapılmaması ve uygun gaz karışımının kullanılmaması gibi nedenlerle meydana geldiğini ifade etmişlerdir. Bir katılımcı da dekompresyonun, daha çok sanayi dalışlarında veya yasadışı avcılık amacıyla yapılan dalışlarda ortaya çıkabilen bir kaza olduğunu ifade etmiştir.

Katılımcıların büyük bir kısmı dalış aktivitesinde karşılaşılan ölümlü kazaların çoğunluğunun iki ve üç yıldız dalıcılar ya da eğitmen statüsünde bulunan kişilerin başına geldiğini, bunun sebebinin ise aşırı özgüven sonucu kendini yeterli görüp dalış limitlerine uymamak olduğunu belirtmişlerdir. Deneme dalışlarında ve bir yıldız dalıcılarla yapılan dalışlarda kaza ve yaralanmalarla karşılaşma sıklığının çok daha az olduğu vurgulanmıştır.

\section{Dalıcı Kaza ve Yaralanmalarını Oluşturan Risk Faktörleri}

Dalıcı kaza ve yaralanmalarını oluşturan çeşitli risk faktörleri bulunmaktadır. Araştırmada bu risk faktörleri dalıcılarla ilgili faktörler, donanımlarla ilgili faktörler, çevresel faktörler ve yönetim ve organizasyon ile ilgili faktörler olmak üzere dört başlık altında toplanmıştır. Dalış eğitmenleriyle yapılan görüşmelerde ortaya çıan risk faktörleri ve kaç katılımcı tarafından vurgulandığı Tablo 2'de özetlenmiştir.

\section{Dalıcılarla İlgili Risk Faktörleri}

Katılımcılar tarafından en fazla vurgulanan risk faktörü eğitim eksikliğidir. Eğitimlerin kalabalık gruplarda ve kısa sürelerde tamamlanması, bilinçsizce yapılması, dalıcıların iyi eğitimin standartlarını bilmemesi ve eğitimde öğrendikleri talimatları uygulamaması, kaza ve yaralanma sıklığını etkilemektedir. 
Tablo 2. Dalış Kaza ve Yaralanmalarını Oluşturan Risk Faktörleri

\begin{tabular}{|c|c|c|}
\hline & Risk Faktörü & Sıklk \\
\hline \multirow{13}{*}{ Dalıcılarla İlgili Risk Faktörleri } & Eğitim eksikliği & 8 \\
\hline & Kondisyon eksikliği & 6 \\
\hline & Talimatları uygulamama & 5 \\
\hline & Sağlık beyan formunu eksik doldurmak & 5 \\
\hline & Yanlış beslenme & 4 \\
\hline & Limitleri zorlama hırsı & 4 \\
\hline & Adaptasyon güçlüğü & 3 \\
\hline & Ruhsal olarak hazır hissetmeme & 3 \\
\hline & Sorumluluk almama & 3 \\
\hline & Aşırı özgüven & 3 \\
\hline & Eş (buddy) kontrolü yapmamak & 3 \\
\hline & Rehber dalıcı talep etmemek & 3 \\
\hline & Emniyet beklemesi yapmamak & 3 \\
\hline \multirow{5}{*}{$\begin{array}{l}\text { Ekipmanlarla İlgili Risk } \\
\text { Faktörleri }\end{array}$} & Tüp ve regülatörlerin günlük ve senelik bakımlarının yapılmaması & 7 \\
\hline & Ekipmanların test ve kontrolünün yapılmaması & 6 \\
\hline & Kompresörlerin hava filtrelerinin değiştirilmemesi & 4 \\
\hline & Tüplerin ayrı bir bölgede sabitlenmemesi & 3 \\
\hline & Teknede veya dalış merkezinde yeterli ekipman bulunmaması & 2 \\
\hline \multirow{6}{*}{ Çevresel Risk Faktörleri } & Hava ve su koşulları & 8 \\
\hline & Görüş kısıtı & 6 \\
\hline & Deniz canlıları & 5 \\
\hline & Deniz trafiği & 4 \\
\hline & Suyun altındaki keskin taşlar ve kayalar & 2 \\
\hline & Suyun içinde kalmış balıkçı ağları & 1 \\
\hline \multirow{11}{*}{$\begin{array}{l}\text { Organizasyon ve Yönetimle } \\
\quad \text { Illgili Risk Faktörleri }\end{array}$} & Dalış öncesi yeterli bilgilendirme yapılmaması & 7 \\
\hline & Dalış rehberinin yetkin olmaması & 6 \\
\hline & Dalış planlamasının çevresel koşullara uygun yapılmaması & 6 \\
\hline & Kapasitenin üzerinde dalıcı ile dalış yapılması & 5 \\
\hline & Dalış eğitmenlerinin aşırı özgüveni & 4 \\
\hline & $\begin{array}{l}\text { Dalıs planlamasının dalıcıların eğitim ve tecrübelerine uygun } \\
\text { yapılmaması }\end{array}$ & 4 \\
\hline & Yeterli dalış personeline sahip olunmaması & 4 \\
\hline & Dalış sırasında teknede eğitimli bir dalııının hazır bulunmaması & 2 \\
\hline & Dalış personelinin ilkyardım konusunda bilgili olmaması & 2 \\
\hline & Acil durumlar için hareket planlarının oluşturulmaması & 2 \\
\hline & Dalıs liderinin grubu kontrol edebileceği şekilde düzenlememesi & 1 \\
\hline
\end{tabular}


Dalıcının eğitmene veya dalış rehberine fazla güvenerek kendi sorumluluğunu almaması, fazla özgüven duyması ve limitleri zorlama hırsı dalış emniyetini tehdit eden unsurlardır. Ayrıca kondisyon eksikliği, anatomik olarak dalışa uygun olmama, bir gün önceden yanlış beslenme, alkol alımı ya da yeterli su içmeme gibi nedenlerle dalıcının fiziksel olarak dalışa hazır olmaması öne çıkan diğer unsurlardır. Kaza ve yaralanmalara sebebiyet veren risk faktörlerinden limitleri zorlama hırsıyla ilgili olarak Katılımcı 6 şu şekilde görüş belirtmiştir:

\begin{abstract}
"Biz diyoruz '18 metreyi sen geçme' ama herkeste 18 metreyi nasıl geçebilirim diye bir düşünce oluyor. İki yıldız oluyorsunuz 30 metre limit ama 'nasil 35 metre derinliğe giderim, konsolda 40 yazsın' falan diyorlar. Kişisel hırslar, limitleri zorlama isteğ $i$ kazaya sebebiyet verir. Sinırlara uymak gerekiyor". (K6)
\end{abstract}

Bunların yanı sıra dalıcının ruhsal olarak kendini dalışa hazır hissetmemesi, dalışa uzun süre ara vermesi nedeniyle adaptasyon güçlügü yaşaması gibi nedenler kaza ve yaralanmalara yol açabilmektedir. Dalıcının dalmadan önce hem kendisinin hem de dalış eşinin donanımını kontrol etmemesi, dalış esnasında ise dalış eşine yeterli uzaklıkta durmaması ve eş kontrolü yapmaması, dalış liderinin ya da rehberinin talimatlarına uymaması öne çıkan diğer risk faktörleridir. Dalışa ruhsal olarak hazır hissetmemenin dalış kazalarına yol açabileceğiyle ilgili Katılımcı 3 görüşlerini şu şekilde belirtmiştir;

\section{"Sen o gün kendini kötü hissediyorsan dalma. Mut- lu değilsen, üzgünsen, kendini motive edemiyorsan dalma, eşini ve kendini kontrol edemezsin, malzeme- ni doğru hazırlayamazsın. Eksik hazırlık kazaya se- bebiyet verir." (K3)}

Hem eğitim eksikliği hem de dalışa odaklanamama gibi sebepler dalıcıların su altında panik yapmasina sebebiyet vermektedir. Görüş bildiren dalış eğitmenlerinin büyük çoğunluğu paniğin kazalara yol açan en önemli etmenlerden biri olduğunu belirtmişlerdir. Şişme bottan veya tekneden atlarken dikkatsiz davranmak, dalış ve çıkış hızına dikkat etmemek, deniz canlılarına fazla yaklaşmak, temas etmek ve rahatsız edici davranışlarda bulunmak ise ciddi kaza ve yaralanmalara yol açan diğer faktörlerdir.
Katılımcıların büyük çoğunluğu dalıcıların bazılarının daha önceden geçirdiği ameliyatları, alt ve üst solunum yolu enfeksiyonlarını, kronik hastalıklarını (hipertansiyon, epilepsi, MS, kalp hastalığı, bel fitığı, vb.), herhangi bir bağımlılığ1 olup olmadığını veya hamilelik durumunu dalış öncesi imzalanan formda belirtmemesinin dalış kazalarına ve hastalıklarına yol açabildiğini belirtmişlerdir. Dalış eğitmenleri dalıcının mevcut hastalı̆̆ını belirtmesi halinde dalış kazalarına ve yaralanmalarına mahal vermemek için bazı durumlarda dalıcının dalış yapmasına izin vermezken bazı durumlarda da o dalıcıya karşı daha dikkatli davranmaktadırlar.

\section{Donanımlarla îlgili Risk Faktörleri}

Dalış esnasında kullanılan en önemli donanımlar basınçlı hava ile dolu bir dalış tüpü ve tüpteki basınçlı havayı önce ara basınca ve sonra da ortam basıncına indirerek solumayı sağlayan bir regülatörden oluşan bağımsız aletli dalış (BAD) donanımıdır (TSSF 2017). Tüplere hava doldurmak amacıyla kullanılan kompresörlerin filtrelerinin değiştirilmemesi ve gerekli bakımlarının yapılmaması, hava analiz cihazlarıla hava kalitesinin test edilmemesi ve özellikle petrol yakıtlı kompresörlerin emiş hattına çekilmesi sonucu tüpün içindeki havaya karbonmonoksit ya da yağ karışması nedeniyle tüpün içindeki hava kalitesi bozulabilmektedir. Bu sebepler zehirlenmelere yol açabilmektedir.

Katılımcıların büyük çoğunluğu tüplerin ve regülatörlerin günlük ve senelik bakımlarının düzenli olarak ve donanım hangi markaysa o markanın yetkili servisindeki uzman kişiler tarafından yapılmasının oldukça önemli olduğunu belirtmişlerdir. Ayrıca tüplerdeki hava kalitesinin kontrol edilmemesi, vana toz kapağının kapatılmaması, tüplerin tekne içindeki ayrı bir bölmede sabitlenmemesi gibi nedenler dalış kazalarına ve yaralanmalarına sebebiyet veren diğer risk faktörleridir. Bunların yanı sıra özelikle tekne ile yapılan dalışlarda teknede yeterli donanım bulunmaması sonucu kişinin bedenine uygun dalış elbisesi giymemesi ve kendisine uygun maske, palet ve patik ile dalış yapamaması diğer risk unsurlarını oluşturmaktadır. Bu konuya ilişkin Katılımcı 5'in görüşleri şu şekildedir; 
"Iyi bir malzeme şart, iyi malzemeden kastım çok kaliteli yüksek fiyatlı bir malzeme değil, sizin standartlarmıza vücudunuza uygun, suyun altında size sorun yaratmayacak bakıml, temiz, düzgün, testleri yapılmış, kullanımı rahat olan malzeme." (K5)

\section{Çevresel Risk Faktörleri}

Katılımcılar tarafından en fazla vurgulanan çevresel risk faktörleri akıntı ve rüzgâr gibi hava ve su koşulları, deniz trafiği ve deniz canlılarıdır. Rüzgâr nedeniyle şişme bottan düşme veya dalış öncesi ve sonrasında teknede kayarak düşme gibi durumlarla karşılaşılabilmektedir. Ayrıca suyun altındaki akıntı, görüş kısıtı, su ve karadaki sıcaklık farkı, suyun altındaki keskin taşlar ve kayalar, deniz canlıları (denizkestanesi, iskorpit, kırlangıç balığı, müren vb.), önceden atılmış ve suyun içinde kalmış balıkçı ağları dalış emniyetini tehdit eden diğer etmenlerdir. Amatör denizcilerin dalış tekneleri tarafından çekilen, teknenin sualtı operasyonu yaptığını gösteren ve uluslararası geçerliliği olan dalış bayrakları ile şamand1ralara dikkat etmeyerek dalış bölgelerine girmesi veya aynı dalış noktasında birden fazla dalış teknesinin olması diğer çevresel risk faktörleridir. Çevresel faktörlerden deniz canlılarıyla ilgili bir katılımcıdan alınan görüş şu şekildedir;

\section{"Deniz canlilarmın suyun altında tehlike yaratması çok nadir olan bir şey. Bizim burada insanları çok fazla etkileyecek bir canlı türü yok. Zaten canlılar bizi gördüklerinde kaçıyorlar. Ama sen kameranı fo- toğraf çekeceğim diye yuvasının içine sokarsan hay- van saldırır."(K9)}

Katılımcıların büyük bir kısmı çevresel risk faktörlerinin dalış profesyonelleri tarafından iyi yönetilmesi durumunda kaza riskinin azalacağ1nı belirtmiştir. Örneğin; akıntının olduğu bölgeyi bilen deneyimli bir dalış liderinin dalıcılara akıntıyla karşılaşabileceklerini ve bu durumda neler yapmaları gerektiğini ön bilgilendirmede belirtmesi gerekmektedir.

\section{Organizasyon ve Yönetimle İlgili Risk Faktörleri}

Görüş bildiren katılımcıların çoğu dalış öncesi dalış yapılacak yerler, karşılaşılabilecek durumlar, takip edilecek rota, sualtında görülebilecek canlılar, bölgenin çevresel şartları ve dalış süresi gibi konularda yeterli bilgilendirme yapılmama- sının yurtdışındaki dalışlara kıyasla Türkiye'de daha sık görülen bir eksiklik olduğunu belirtmişlerdir. Rehberin yetkin olması ve dalışta iyi bir lider olduğunu gruptaki dalıcılara göstermesi gerekmektedir. Bunun yanı sira teknede veya botta bulunan eğitmen ve asistan sayısı dalıcı sayısına göre ayarlanmalı ve gerektiği durumlarda asistan ve eğitmen sayısı artırılmalıdır.

Katılımcıların büyük çoğunluğuna göre dalışın çevresel koşullara (akıntı, fırtına vb.) ve dalıcıların tecrübe ve eğitimlerine uygun planlanmaması ve kapasitenin üzerinde dalıcı ile dalış yapılması en önemli risk faktörlerdir. Ayrıca dört yıldız kuralına uymayarak dalıcıların yanlış eşleştirilmesi, dalışın derinlik limitlerine ve dip zamanına uygun yapılmaması, donanımın dalış merkezi tarafından dalış öncesinde kontrol edilip kayıt altına alınmaması risk oluşturan unsurlar olarak öne çıkmaktadır. Bunların yanı sıra dalış gruplarının sualtında dalış liderinin grubu rahatça görüp kontrol edebileceği şekilde düzenlenmemesi ve dalış sırasında teknede eğitimli bir dalıcının hazır bulunmaması gibi organizasyonel risk faktörleri de kaza ve yaralanmalara sebebiyet verebilmektedir.

\section{Dalış Kazalarının Nasıl Önlenebileceğine Yönelik Görüşler}

Dalış kazalarını önlemeye ya da azaltmaya yönelik uygulanabilecek tedbirlerle ilgili soruya cevaben katılımcıların büyük çoğunluğu öncelikle iyi bir eğitim verilmesinin şart olduğunu belirtmişlerdir. Bu konuda TSSF'nin denetimlerini yeterli bulanlar olduğu gibi, denetimlerin eksik olduğu$\mathrm{nu}$, eğitimin kalitesinin yeteri kadar denetlenmediğini belirtenler de olmuştur. Katılımcılar eğitimin uzun zamana yayılması gerektiğini, eğitim kitaplarının net ve anlaşılır olmasının önemini ve gerekli bilgilerin daha kolay hatırlanmasını sağlayan sistematik ve temelden başlayan bir eğitim müfredatının uygulanması gerektiğini vurgulamişlardir.

Kaçak okulların kapatılmasının, çok cüzi fiyatlara dalış eğitimiyle beraber her şey dâhil aktivite tatili satan firmaların denetlenmesinin, belirli bir dalış merkezine bağlı olmadan çalışan eğitmenlerin engellenmesinin ve eğitimin sadece 
yetkili dalış merkezlerinde alınabilmesinin kazaları azaltacağını savunmuşlardır. Katılımcıların birçoğu eğitim kitaplarının bu işten kazanç elde etmeyen gönüllüler tarafından değil profesyoneller tarafindan daha sistematik ve kolay hatırlanabilecek şekilde yazılmasının kitapların işlevini artıracağını belirtmiştir. Ayrıca TSSF'nin gizli müşteri uygulaması ile dalış merkezlerini habersizce denetlemesini öneren katılımcılar da olmuştur. Dalış turizmi emniyetini sağlamada en fazla vurgulanan unsurlardan biri olan eğitim kalitesinin nasıl artırılabileceğiyle ilgili Katılımcı 10 'dan alınan öneriler şu şekildedir;

\begin{abstract}
"Bizde mevcut olmayan ama başka sistemlerde uygulanan denetim sistemini uygulamak gerekiyor. Sen eğitimini aldiktan sonra federasyon sana bir mail göndermeli; eğitimde kaç dalış yaptın, dalışların kaç tanesi sı̆̆ sudaydı, kaç tanesi derin sudaydı? Eğitmenin seviyesi neydi, eğitmenin kimdi? Eğitmenin bütün dalışlar boyunca seninle beraber miydi? Ĕ̆itmenin eğitim süresince seni riske sokacak herhangi bir eylem içerisine girdi mi? gibi. Yaptlan yanlışları ortaya çıkarmanın yolu da bu eğitimi almış, bu süreci tamamlamış kişilere doğru soruları içeren anketler göndermektir." (K10)
\end{abstract}

Herhangi bir kaza ve yaralanma durumunda dalış operasyonunu durdurup, en hızlı şekilde kıyıya ulaşan ve 112 Acil Çağrı Merkezi'ni arayan dalış eğitmenlerinden bazıları sağlık personelinin de bazı durumlarda dalış kazalarına nasıl müdahale edileceğiyle ilgili doğru bilgiye sahip olmadığını belirtmiştir. Ayrıca boğulmak üzere olan birine acil yardım edilebilmesi için dalış teknesi, bot veya merkezlerinde saf oksijen tüpünün mutlaka bulundurulması gerektiğini vurgulamişlardır.

Araştırmada görüş bildiren dalış eğitmenlerinin çoğunluğu dalıcıların TSSF tarafından hazırlanan ve dalış öncesi doldurulması gereken dalıcı ve dalış merkezi arasında yapılan bir sözleşme niteliğindeki formu eksik doldurduklarını ve mevcut hastalıklarını sakladıklarını belirtmişlerdir. Bu kapsamda dalıcıların aile hekiminden ya da en azından bir kulak-burun-boğaz uzmanından altı ay geçerli dalış yapabilir raporu almasının karşılaşılabilecek dalış kaza, yaralanma ve hastalıklarını azaltabileceğini beyan etmişlerdir.
Katılımcıların bazıları dalış merkezlerini bağlayan üç farklı yönetmelik olduğunu belirtmiştir. Bunlar; TSSF'nin Donanımlı Dalış Yönetmeliği, Sahil Güvenlik Komutanlığı'nın Profesyonel Sualtıadamları Yönetmeliği ile T.C. Kültür ve Turizm Bakanlığı'nın Turizm Amaçlı Sportif Faaliyet Yönetmeliği'dir. Bazen bu yönetmeliklerin birbiriyle çeliştiği veya uygulamada boşluklar kaldığ1 vurgulanmıştır. Örneğin; T.C. Kültür ve Turizm Bakanlığı'nın Turizm Amaçlı Sportif Faaliyet Yönetmeliğine göre dalış merkezlerinin su üstünde bir deniz aracına sahip olması gerekirken (T. C. Kültür ve Turizm Bakanlığ 1 2011), dalış merkezleri ve sualtı spor kulüplerinin uyacakları standartları belirleyen TSSF'nin Donanımlı Dalış Yönetmeliği'ne göre dalış kuruluşları, uygulamalı deniz eğitimlerini yaptırabilmek amacıyla geçici süreyle başka bir dalış kuruluşunun tekne ve donanımlarından yararlanabilirler (TSSF 2017). Aynı zamanda TSSF'nin dalış eğitmeni, Sahil Güvenlik Komutanlığı'nın Profesyonel Sualtıadamları Yönetmeliğine göre balıkadam olarak tanımladığı tüplü dalış yapan kişilerin yeterlik belgesi alma şartları, almaları gereken eğitimler ve sınav içerikleri farklılık göstermektedir (Resmigazete 2016). Katılımcilardan baz1ları TSSF'nin Donanımlı Dalış Yönetmeliği'nde yer alan 14 yaş sınırının çok kısıtlayıcı olduğunu belirtirken, bir katılımcı ise yönetmeliklerde mağara dalış standartlarının yer almadığına dikkat çekmiştir. Bu çelişkileri ortadan kaldırmak için tüm paydaşların (yerel yöneticiler, güvenlik birimleri, TSSF, dalış merkezi temsilcileri ve malzeme ithalatçıları) katılımı ile ortak bir yönetmelik hazırlanması gerektiği belirtilmiştir. Katılımcılardan biri ise dalış merkezlerinin A, B, C grubu dalış merkezi gibi yetkilerine göre derecelendirilerek sınıflandırılması gerektiğini ve böylece sadece belirli grup dalış merkezlerinin yetkisi dâhilindeki eğitim ve dalışları yapabilmesi gerektiğini belirtmiştir.

Bunlara ek olarak amatör denizcilerin ve balıkçıların dalış yapanlara zarar vermemesi için dalış bölgelerinin korunarak dalış noktalarına girişin engellenmesi gerektiği vurgulanmıştır. Katılımcıların bir bölümü mevcut durumda dalış noktalarının sadece kâğıt üzerinde belirlendiğini, aslında dalış noktalarının TSSF'ye kayıtlı deneyimli 
bir uzman tarafından yerinde gözlemlenerek dalışa uygun olup olmadığının tespit edilmesinin daha yerinde bir uygulama olacağını belirtmişlerdir. Katılımcı 4 dalış yerlerinin korunmasıyla ilgili şu şekilde görüş belirtmiştir;

"Bir kere suyun altındayken patlama oldu, dinamit
attılar sersemledim, balık tutmak amacıyla atıyorlar,
bana denk geldi. Hortum patladı, vanayı açıp hava
aldım... Dalıs yerleri, noktaları çok önemli. Bazı
yerlerde çok fazla tekne oluyor, çapa atıyorlar aşağı-
ya, dalış yerleri korumalı olmalı." (K4)

Araştırmaya katılan dalış merkezi temsilcilerinden birkaçı riskli durumlar için tedbir alınması ve karşılaşılabilecek her olağandışı durum için hareket planlarının oluşturulması gerektiğini beyan etmiştir. Örneğin; dalış grubunu kaybederek gruptan kopan bir dalıcının o anda ne yapması gerektiğinin dalış öncesinde yapılan bilgilendirme toplantısında belirtilmesi gerekmektedir. Bir katılımcı ise dalış organizasyonunda sualtındayken birbirini takip eden zincirleme ikili gruplar yerine hem dalış liderinin ya da rehberinin diğer dalıcıları hem de dalıcıların dalış liderini rahatlıkla gözlemleyebildiği uçak modelinin uygulanmasının kazaları önlemede etkili bir yöntem olabileceğini vurgulamıştır.

\section{SONUÇ VE TARTIŞMA}

$\mathrm{Bu}$ araştırmanın amacı dalış turizmine katılan bireylerin karşılaştıkları kaza, yaralanma ve hastalıkları tespit etmek, bu durumları ortaya çıkaran risk faktörlerini saptamak ve emniyeti tehdit eden unsurların ortadan kaldırılması için yapılması gerekenleri ortaya koymaktır. Bu bağlamda dalış turizminde en sık karşılaşılan kaza, yaralanma ve hastalıklar tüp düşmesi, kayarak düşme, kulak zarı zedelenmesi, kesik ve küçük çizikler, sualtında oluşabilecek kramp ve spazmlardir. Bu bulgular macera turizmi aktivitelerinde en fazla karşılaşılan kazaların ciddi kazalardan ziyade kaymak, sendelemek ve düşmekten kaynaklanan yaralanmalar olduğunu bildiren çalışmalarla benzerlik göstermektedir (Bentley, Page ve Macky 2007; Bentley, Cater ve Page 2010). Çalışmada, dalıcı kaza ve yaralanmalarını oluşturan risk faktörleri Bentley, Cater ve Page'in (2010) çalışmasına benzer bir şekilde dört kategoride gruplanmıştır. Bunlar dalıcılarla ilgili, donanımla ilgili, çevresel ve organizasyon/yönetimle ilgili risk faktörleridir.

Katılımcılar tarafından en fazla vurgulanan risk faktörleri dalıcılarla ilgili risk faktörleridir. Heyecan ve stres sonucu oluşan panik, eğitim eksikliği sonucu donanımın yanlış kullanılması ve fazla özgüven duyma geçmiş çalışmalarda da öne çıan unsurlardır (Edmonds ve Walker 1989; Miller ve Taubman-Ben-Ari 2004; Dimmock ve Wilson 2009). Buna karşın dalış liderinin veya rehberinin talimatlarına uymama ve mevcut tıbbi hastalıklarını dalış öncesi beyan etmemenin risk faktörü oluşturduğuna yönelik ortaya çıkan bulgular bu çalışmayı farklı kılmaktadır.

Dalış aktivitesinde kullanılan donanımların bakımlarının düzenli yapılmaması dolaylı olarak yönetimsel olmakla birlikte bu çalışmada donanımla ilgili bir risk faktörü olarak ele alınmıştır. Dalış operatörleri tarafından uygulanması gereken risk değerlendirme yöntemlerinden donanımların düzenli kontrol edilmesi ve personelin bu konuda eğitilmesinin kazaları önleyici bir tedbir olduğu daha önceki çalışmalarda da (Page, Bentley ve Walker 2005) öne çıkmıştır. Akıntı, rüzgâr, tekne trafiği ve deniz canlıları ise dalış kaza ve yaralanmalarını oluşturan çevresel risk faktörleridir. Dimmock ve Wilson'ın (2009) dalış konfor ve emniyetini etkileyen görsel kisit kategorisinde ele aldığı suyun bulanık olması sonucu oluşan görüş kısıtı bu çalışmada çevresel risk faktörleri altında ele alınmıştır.

Dalıcılarla ilgili faktörlerden sonra en fazla vurgulanan risk faktörleri doğru gruplandırma yapmama, dalıcıyı eksik bilgilendirme, yanlış planlama gibi yönetim ve organizasyonla ilgili ortaya çıkan risk faktörleridir. Dalış öncesi iyi bir ön bilgilendirme yapılması, dalıcıların sualtında karşılaşabilecekleri riskli durumlara ilişkin önceden uyarılması kaza ve yaralanmaları önlemede önemlidir. Geçmiş çalışmalarla benzer şekilde iletişimin dalış emniyeti açısından rolü vurgulanmıştır (Page, Bentley ve Walker 2005; Buckley 2010). Riskli durumlar için tedbir alınmasına dikkat çeken Coxon, Dimmock ve Wilks'in (2006) araştırma sonuçlarıyla benzer bir şekilde karşılaşılabilecek her olağanüstü durum için hareket 
planlarının oluşturulmasının dalış öncesinde, s1rasında ve sonrasında karşılaşılabilecek kaza, yaralanma ve hastalıkları azaltmada önemli bir rol oynayacağı açıktır. Ayrıca rehber-dalıcı sayısının dengeli bir şekilde ayarlanması ve dalıcı sayısına göre organizasyon yapılması dalış emniyeti açısindan oldukça önemlidir.

Araştırma sonuçları dalıcılara iyi bir eğitim verilmesinin dalış kazalarını önlemenin ya da azaltmanın öncelikli şartı olduğunu göstermektedir. Bu bağlamda TSSF eğitimin kalitesini kontrol etmeli, dalış merkezleri bu konuda denetlenmeli, eğitim kitapları sistematik ve anlaşılır olmalıdır. Ayrıca dalış merkezlerinin uymak zorunda olduğu birbiriyle çelişen yönetmelikler yerine bütün paydaşların fikirleri alınarak uzlaşmaya varılarak oluşturulan tutarlı tek bir yönetmeliğin uygulamaya konması risk faktörlerini azaltmada gereklidir.

Araştırma kapsamında İzmir ilinde faaliyet gösteren dalış merkezlerinde çalışan deneyimli dalış eğitmenleri ile derinlemesine görüşmeler gerçekleştirilmiştir. Gelecek çalışmalarda dalış turizmine katılan bireylerin emniyet algılarını ölçmek amacıyla nicel araştırmalar yapılabilir ya da aynı çalışma farklı destinasyonlardaki dalış merkezi eğitmenleri üzerinde uygulanarak sonuçların genellenebilirliği arttırılabilir.

\section{KAYNAKÇA}

Bentley, T. A., Cater, C. ve Page, S. J. (2010). Adventure and Ecotourism Safety in Queensland: Operator Experiences and Practice, Tourism Management, 31 (5): 563-571.

Bentley, T. A., Page, S. J. ve Macky, K. A. (2007). Adventure Tourism and Adventure Sports Injury: The New Zealand Experience, Applied Ergonomics, 38 (6): 791-796.

Buckley, R. (2010). Communications in Adventure Tour Products: Health and Safety in Rafting and Kayaking, Annals of Tourism Research, 37 (2): 315-332.

Cbi.eu. (2018). Dive Tourism From Europe, https://www.cbi.eu/ market-information/tourism/dive-tourism/europe/, Erişim tarihi: 5 Kasım 2018.

Coxon, C., Dimmock, K. ve Wilks, J. (2008). Managing Risk in Tourist Diving: A Safety-Management Approach. İçinde B. Garrod ve S. Gössling (Editörler), New Frontiers in Marine Tourism: Diving Experiences, Sustainability, Management (ss. 201-219). Amsterdam: Elsevier.

Creswell J. W. (2013). Qualitative Inquiry \& Research Design Choosing Among Five Approaches. Los Angeles, CA: SAGE Publications.
Dimmock, K. ve Musa, G. (2015). Scuba Diving Tourism System: A Framework for Collaborative Management and Sustainability, Marine Policy, 54 (1): 52-58.

Dimmock, K. ve Wilson, E. (2009). Risking Comfort? The Impact of in-Water Constraints on Recreational Scuba Diving, Annals of Leisure Research, 12 (2): 173-194.

Duman, T., Kozak, M. ve Uysal, M. S. (2007). Turizmde Ürün Çeşitliliği Yoluyla Ürün Değeri Oluşturma: Türkiye'deki Arz Kaynakları Üzerine Bir İnceleme, Anatolia: Turizm Araştırmaları Dergisi, 18 (2): 206-214.

Dünya Turizm Örgütü. (2016). PATA Tourism Updates, http:// cf.cdn.unwto.org/sites/all/files/docpdf/unwtopatatourismupdatesissue6v2final.pdf, Erişim tarihi: 10 Eylül 2018.

Edmonds, C. W. ve Walker, D.G. (1989). Scuba Diving Fatalities In Australia and New Zealand. 1. The Human Factor, South Pacific Underwater Medicine Society Journal, 19: 94-104.

Fuchs, G., Reichel, A. ve Shani, A. (2016). Scuba Divers: The Thrill of Risk or the Search for Tranquility, Tourism Recreation Research, 41 (2): 145-156.

Lamb, J. B., True, J. D., Piromvaragorn, S. ve Willis, B. L. (2014). Scuba Diving Damage and Intensity of Tourist Activities Increases Coral Disease Prevalence, Biological Conservation, 178 (1): 88-96.

Maccarthy, M., O'neill, M. ve Williams, P. (2006). Customer Satisfaction and Scuba-Diving: Some Insights from the Deep, The Service Industries Journal, 26 (5): 537-555.

Miller, G. ve Taubman-Ben-Ari, O. (2004). Scuba Diving Risk Taking-A Terror Management Theory Perspective, Journal of Sport and Exercise Psychology, 26 (2): 269-282.

Musa, G. ve Dimmock, K. (2012). Scuba Diving Tourism: Introduction to the Special Issue, Tourism in Marine Environments, 8 (1-2): 1-5.

PADI (2017). About Padi, https://www.padi.com/about-padi, Erişim tarihi: 5 Kasım 2018.

Page, S. J., Bentley, T. ve Walker, L. (2005). Tourist Safety in New Zeland and Scotland, Annals of Tourism Research, 32 (1): 150-166.

Patton, M. Q. (2002). Qualitative Research \& Evaluation Methods. California: Sage Publications.

Resmigazete (2016). Yönetmelik. http://www.resmigazete.gov. trleskiler/2016/03/20160320-17.htm, Erişim tarihi: 9 Ocak 2019.

T. C. Kültür ve Turizm Bakanlığı (2011). Turizm Amaçlı Sportif Faaliyet Yönetmeliği, http://teftis.kulturturizm.gov.tr/ TR-14497/turizm-amacli-sportif-faaliyet-yonetmeligi.html, Erişim tarihi: 9 Ocak 2019.

TSSF (2017). TSSF/CMAS Bir Yıldız Dalıcı Ĕ̆itimi Kitabı. İstanbul: CNS Ajans Tasarım Reklam Org. San. Ltd. Şti.

TSSF (2017). Yönetmelik ve Talimatlar, https://tssf.gov.tr/ yonetmelik-ve-talimatlar/, Erişim tarihi: 10 Ocak 2019.

TSSF (2018). Dalış/Cankurtarma, Uzman Eğitim Merkezleri ve Kulüplerimiz, https://tssf.gov.tr/dalis-cankurtarma-uzman-egitim-merkezleri/, Erişim tarihi: 2 Kasım 2018.

Wolcott, H. F. (1994). Transforming Qualitative Data: Description, Analysis and Interpretation. Newbury Park, CA: Sage. 
Yarmacı, N., Keleş, M. Ç. ve Ergil, B. (2017). Su Altı Dalış Turizminin Mevcut Durumu, Sorunları ve Geliştirilmesine Yönelik Öneriler: Kaş Örneği, Güncel Turizm Araştırmaları Dergisi, 1 (1): 66-87.

Yaşar, O. (2011). Saros Körfezi Kıyılarında Su Altı Dalış Turizmi, Zeitschrift für die Welt der Türken, Journal of Word of Turks, 3 (1): 33-55.

Yıldırım, A. ve Şimşek, H. (2013). Sosyal Bilimlerde Nitel Araştırma Yöntemleri. Ankara: Seçkin Yayıncllık.

\section{Ek 1. Katılımcılara Yöneltilen Görüşme Soruları}

Giriş Soruları

1. Merkezinize gelen turist profili hakkında bilgi verebilir misiniz?

2. Hangi kanallardan size ulaşıyorlar?

3. Merkezinize gelenlerin seyahat motivasyonu öncelikli olarak dalış yapmak mi?

Konuyla İlgili Sorular

1. Dalış öncesi, sırası ve sonrasında en sık karşılaşılan kaza ve yaralanmalar nelerdir?
2. Dalıcı yaralanmaları ve kazalarını oluşturan risk faktörleri nelerdir?

3. Riskli durumları nasıl çözersiniz?

4. TSSF (Türkiye Sualtı Sporları Federasyonu) tarafından belirlenen dalış talimatlarını emniyet açısından yeterli açısından buluyor musunuz?

5. Dalış merkezi olarak kazaları önleme konusunda bir eksikliğiniz olduğunu düşünüyor musunuz?

6. Bu kazalar nasıl önlenmeli? Hangi tedbirler alınmalı?

7. Kazalarla karşılaşma sıklığı yerli ve yabancı dalış turistlerinde farklılık gösteriyor mu?

Demografik Sorular

1. Yaşınız kaç?

2. Eğitim seviyeniz nedir?

3. Yabancı dil bilginiz var mi?

4. Kaç yıldır eğitmenlik yapıyorsunuz?

5. Farklı dalış merkezlerinde çalıştınız mı? 


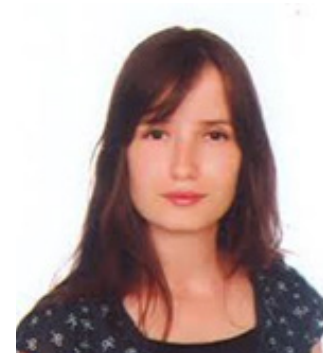

Hümeyra DOĞRU

Boğaziçi Üniversitesi Uygulamalı Bilimler Yüksekokulu Turizm İ̧̧letmeciliği Bölümü’nden mezun oldu (2009). Yüksek lisans derecesini Dokuz Eylül Üniversitesi Sosyal Bilimler Enstitüsü, Turizm İşletmeciliği Dalı'ndan aldı (2015). Doktora eğitimine Dokuz Eylül Üniversitesi Turizm İşletmeciliği Bölümü'nde devam etmektedir. Turizm sektöründe Metglobal firmasında çevrimiçi pazarlama uzmanı olarak (2009-2011), Booking.com firmasında Türkiye Otelleri Koordinatörü olarak çalıştı (2011-2013). Dokuz Eylül Üniversitesi İşletme Fakültesi Turizm İşletmeciliği Bölümü’ne Araştırma Görevlisi olarak atandı (2013). Halen Dokuz Eylül Üniversitesi İşletme Fakültesi Turizm İşletmeciliği Bölümü’nde görev yapmaktadır. Temel çalışma alanları, turizm pazarlaması, turistik tüketici davranışı ve elektronik turizmdir.

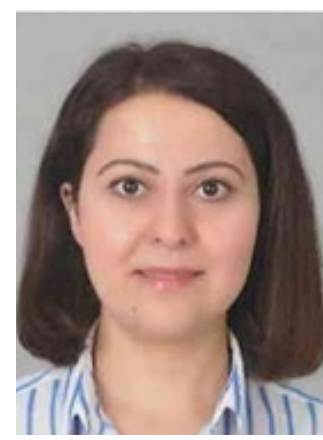

Burcu ÇELIK

İstanbul Üniversitesi Mühendislik Fakültesi Deniz Ulaştırma İşletme Mühendisliği Bölümü’nden mezun oldu (2009). Yüksek lisans derecesin Dokuz Eylül Üniversitesi Deniz Ulaştırma İşletme Mühendisliği Dalı́ndan aldı (2014). Halen Dokuz Eylül Üniversitesi Sosyal Bilimler Enstitüsü Denizcilikte Emniyet, Güvenlik ve Çevre Yönetimi Doktora Programı́na devam etmektedir. ÖYP Araştırma Görevlisi olarak Recep Tayyip Erdoğan Üniversitesi Denizcilik Fakültesi'nde göreve başlamıştır (2011). Daha sonra yükseköğretim için Araştırma Görevlisi olarak atanmıştır (2012). Halen Dokuz Eylül Üniversitesi Denizcilik Fakültesi'nde görevine devam etmektedir. Temel çalışma alanları, deniz ulaştırmasında emniyet, denizcilikte insan kaynaklarıdır.

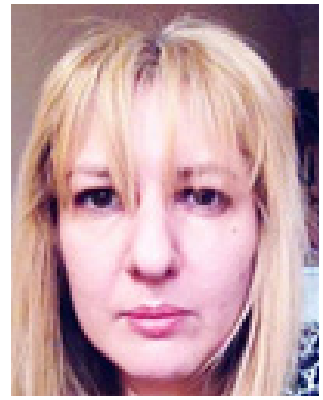

\section{Burcu Selin YILMAZ}

Dokuz Eylül Üniversitesi İşletme Fakültesi Turizm İşletmeciliği Bölümü’nden mezun oldu (1997). Yüksek lisans derecesini Dokuz Eylül Üniversitesi Sosyal Bilimler Enstitüsü Turizm İ̧̧letmeciliği Ana Bilim Dalı'ndan (2000), doktora derecesini Dokuz Eylül Üniversitesi Sosyal Bilimler Enstitüsü Turizm İşletmeciliği Ana Bilim Dalı́ndan aldı (2005). Dokuz Eylül Üniversitesi'nde çalışmaya başladı (1997) Doçentlik unvanını Pazarlama alanında aldı (2011). Profesörlüğe Dokuz Eylül Üniversitesi'nde yükseltildi (2017). Halen Dokuz Eylül Üniversitesi İșletme Fakültesi Turizm İşletmeciliği Bölümü’nde görev yapmaktadır. Temel çalışma alanları, tüketici davranışı, turizm pazarlaması, pazarlama iletişimi ve elektronik turizmdir. 